\title{
The Effect of Peer Corrective Recast in CALL as a Language Teaching Methodology on Teaching Grammar to Intermediate Iranian English Foreign Language Students
}

\author{
Mostafa Rahimi Rad \\ Department of English Languges, Allameh Tabataba'i University, Tehran, Iran \\ Email address: \\ Mostafa.rahimi@yahoo.com \\ To cite this article: \\ Mostafa Rahimi Rad. The Effect of Peer Corrective Recast in CALL as a Language Teaching Methodology on Teaching Grammar to \\ Intermediate Iranian English Foreign Language Students. International Journal of Applied Linguistics and Translation. \\ Vol. 4, No. 1, 2018, pp. 9-17. doi: 10.11648/j.ijalt.20180401.12
}

Received: February 15, 2018; Accepted: March 19, 2018; Published: April 10, 2018

\begin{abstract}
The use of internet as a teaching tool is predominant all around the world and teachers try to devise it in order to accelerate and facilitate language learning for their students. However in Iran, few studies have concentrated on this type of methodology and it is rarely practiced among English language instructors. Thus this study aimed at investigating the effect of CALL methods on teaching English grammar in general and passive voice in particular to Intermediate EFL students. For this purpose the researcher took advantage of weblogs as a CALL program. The students who were being taught by the researcher were given a pretest at the beginning of the course and then a subject to write about each week on their weblog. They were advised to use more passive voice than active in their essays. Consequently their performance was evaluated in 2 ways: one group by their peers through recast and the other group by the teacher, via traditional methods to see which method was more effective in teaching grammar, peer corrective recast or instructor's corrective hints. The text book used by the instructor during this experimental course was Top Notch. The number of errors could determine the results of pretest and posttest. Then frequency, mean and Standard Deviation were used for providing the results and statistics. Finally, a T-test was devised in order to verify the difference between means of both groups. This study found that corrective recast had statistically no clear impact on grammar acquisition of the Iranian EFL learners.
\end{abstract}

Keywords: CALL, EFL, Recast

\section{Introduction}

Nowadays, the use of internet as a teaching tool is predominant all around the world and teachers try to use this tool to accelerate and facilitate language learning for their students.

On the other hand, as stated by Richards and Schmidt [2002], feedback in teaching is defined as any comment or information which is given to the learners regarding their success on learning tasks or tests, which is provided by the teacher or any other person. Feedback is divided to many categories including auditory feedback, error correction, recast, kinesthetic feedback, proprioceptive feedback, etc.

Although teacher feedback which is usually written with red pen at the bottom of the students' written assignments can be very beneficial for the students in many ways, it can also be quite discouraging to them as it is usually accompanied by stress and anxiety for the students, which is considered to be harmful for them if it continues to happen and can diminish their motives for learning.

With the development of technology nowadays, it is not merely the responsibility of teachers to give feedback on students' performance and feedback can also be provided by the peers, Computer-Assisted Language Learning programs (CALL), or even the students themselves to their own activities. Among all other types of feedback, peer feedback seems to be an effective way of receiving feedback in the improvement of the quality and accuracy of written assignments of the students. They read and respond to drafts of written assignments provided by their peers and then they have the opportunity to revise their work before submitting it to their instructor. According to Rollinson [2005], peer 
response in the writing classroom is considered as a time consuming activity, but it is obviously not a waste of time. Bartholomae [1980] also reported that teaching students to edit their texts is easier than teaching them to write correctly at transcription point. In other words teaching students to become critical readers, we are helping them to become more self-reliant writers who can simultaneously be self-critical and also be able to self-edit their own writing assignments. However, it seems that most language learners prefer to receive some kind of feedback on their writings in order to know more about their weak and strong points. There have been many studies conducted by various researchers regarding this issue and it seems that peer feedback has been one of the most interesting types of feedback which can be given to the language learners' assignments, in language classes. It appears that students feel more convenient with peer feedback since in this type of feedback they receive it from their peers and friends. As a result it can help them feel less anxious or nervous. Peer feedback is supported by various concepts in education like Vygotskian? socio-cultural theory, the process approach to the teaching of writing, and the theory of well-established role of student-student interaction in second language acquisition proposed by Liu and Hansen [2002]. In cooperative learning which is proposed by Johnson and Johnson [1998], there are five basic principles in which peer feedback fits very well. These principles are: positive interdependence, face to face promoted interaction, individual accountability, interpersonal and small group skills, and processing. According to Murphy and Jacobs [2000], while giving peer feedback, students learn collaborative skills as they work with each other. Nevertheless, peer feedback is still a controversial issue in English language studies. Its effectiveness is not completely established in language classes. For example, Carson and Nelson [1996] found out that this type of feedback caused many problems for ESL students of East Asia who had little or no experience of collaborative learning. In addition Zhang [1995] also reported that the students preferred to receive teacher feedback rather than peer-feedback on their assignments. Therefore it can be concluded that recently peer feedback is being used in language classes and is becoming common in language learning and teaching pedagogy but it needs more investigation.

Another way to provide students with effective feedback nowadays seems to be the kind of feedback language learners can receive from different types of CALL programs. Powell [1998] has suggested that CALL courseware can provide learners with language learning around question and answer procedures within controlled environments. According to him, grammar reinforcement can be more frequently utilized in higher education than for beginners. Although CALL has been used on large computers for more than twenty years, since the introduction of micro-computers its use has become wide spread among EFL teachers [Fox, 1984]. In line with the use of computers in language learning, one important facility in achieving this aim is the use of internet. For example Li and Cao [2006] claimed that one advantage of using computer-mediated communication in foreign language learning via internet is that new technologies provide us with some methods of facilitating language learning and also challenging the traditional methods of learning and teaching. In the modern era teachers who want to adapt themselves to the rapid growth of technology must be ready to innovate some new teaching methods and context in order to contribute to foreign language teaching and learning.

\subsection{Purpose of the Study}

Considering the previously conducted researches in the field of computer-assisted language learning and teaching and the different types of feedback which can be given to language learners' assignments, the present study attempted to combine the peer recast with computer-assisted language learning programs and investigate the effectiveness of receiving peer corrective recast in CALL on the development and improvement of grammar knowledge among the students. However in order to be more specific in terms of grammar, the researcher has limited the scope of the study to teaching Passive voice to intermediate language learners.

\subsection{Review of Literature}

CALL is an abbreviation which stands for Computer Assisted Language Learning. It is a term used by teachers and students to explain the use of computers as part of a language course [Hardisty\& Windeatt, 2000]. CALL is by tradition defined as a means of "presenting, reinforcing and testing" special language features.

\subsection{Error Correction}

According to Richards [1985], the word "error" is used for a form of structure which a native speaker believes is unacceptable due to its inappropriate use or the use of a linguistic item in a manner in which a native speaker of that language regards as showing faulty or an incomplete learning. During the past four decades, a number of both primary and secondary researches have been done on the subject of error correction in L2 writing [Lalande, 1982; Kepner, 1991; Truscot, 1996; Ferris, 2002, 2003]. It is obvious that providing feedback is a useful method for treating errors. Feedback has got many different types which will be discussed here.

\subsection{Direct vs. Indirect Feedback}

Many studies have differentiated between direct and indirect feedback and made efforts to find out which one of these two strategies can cause greater accuracy [Ferris, 1995; Ferris \& Hedgcock, 1998; Robb, Ross, and Shortreed, 1986]. Gue'nette [2007] mentioned that explicit or direct feedback is referred to the kind of feedback in which the teacher indicates the error and provides the correct form of it. Ferris [2002] asserted that direct feedback can be dangerous because the teacher may misinterpret his/her students meaning and put his/her own words in their mouths. However this kind of feedback can be beneficial for beginner 
students and also in the case of the errors which are untreatable (i.e., errors which learners cannot correct by themselves, like vocabulary or syntax errors).

Alternatively Chandler [2003] indicated that direct correction is very useful for producing accurate revisions and students usually prefer this kind of feedback because it can be used more easily in their revisions than several drafts. However Chandler has also mentioned that the students feel that they can learn more from self-correction and teachers may spend less time on underlining errors on the first draft. On the other hand indirect strategies of providing feedback refer to situations in which the teacher points out that there is an error but do not offer a correction, thus leaving the learners to identify and correct it themselves. Implicit strategies in detail include recast, repetition, clarification request, and comprehension check. Recast refers to the teacher's reformulation of all or a part of the learner's utterance [Lightbown and Spada, 1999]

In repetition the teacher repeats the student's exact utterance with rising intonation on the erroneous part, in order to inform the learner about the existence of an error. In a study Ferris and Roberts [2001] reported that $60 \%$ of the errors made by the subjects were revised through underlining. They also reported that $64 \%$ of the errors were revised by underlining plus coding. In contrast to the studies which show that both teachers and students prefer direct or explicit feedback rather than indirect feedback [Ferris and Roberts, 2001; Ferris, Cheyney, Komura, Roberts, \& McKee, 2000; Komura, 1999; Rennie, 2000; Roberts, 1999] there are many other studies which reveal that indirect feedback can also lead to similar or sometimes even greater levels of accuracy in time [Ferris et al., 2000; Ferris and Helt, 2000; Frantzen, 1995; Lalande, 1982; Lee, 1997; Robb et al., 1986]. Anyway, neither Lalande nor the Robb et al. included a control group who received no correcting feedback in their studies and none of them found a statistically significant difference between these treatment situations.

Alternatively, some studies like studies done by Lee [1997] and Ferris and Roberts [2001] included control groups which received no corrective feedback. In Lee's study on EFL college students in Hong Kong, results showed a significant effect for the group whose errors were underlined, compared with those who received no corrective feedback on their errors. Ferris and Roberts [2001] investigated the impacts of three different feedback treatments and the results showed that both error feedback groups considerably outperformed the control group which received no feedback. However, like Robb et al. [1986] they found that there were no main differences between the group which was given coded feedback and the group which was not. In one study done by Ferris et al [2000] the effects of different treatment conditions on both text revisions and new pieces of writing were investigated. Discussing the results of the research, Ferris [2002] mentioned that direct error correction led to more correct revisions with the percentage of $88 \%$, than indirect error feedback which was $77 \%$. However, over the course of the semester, students who received indirect feedback reduced their error frequency percentages substantially more than those who received direct feedback.

In contrast with this growing but far from convincing body of research on the written feedback strategies of teachers, nearly no researcher has investigated the impact of other feedback strategies, such as teacher-student conferences, peer editing sessions, and the maintenance of error logs [Ferris, 2002]. Some teachers of writing believe that one-onone teacher-student conferences is potentially more successful than written corrective feedback because they afford an opportunity for explanation, instruction, and compromise [Ferris, 2002; Ferris \& Hedgcock, 1998], however, lack of published empirical research on this option means that this popularly held idea cannot be taken as a proof of helpfulness.

\section{Empirical Studies on Error Feedback}

Normally, claims about the impact of error correction have been made on two fronts; first, those who are proponents of error correction, and second, those who are against error correction. Williams [2003] suggested that most of the regularly used and reliable methods of teacher feedback on written assignments are unsuccessful when it comes to growing and encouraging students' English writing skills. Williams [2003] also mentioned that methods such as outright correction of surface errors, inconsistently marking errors, uncertain and unclear responses on content have all been discovered to have little positive and sometimes negative impact on student writing abilities. In his idea, teachers should increase more systemized and reliable types of feedback that take advantage of the process approach and make it obvious to students what the feedback means and what they ought to do with it.

Furthermore, teachers need to publicize and teach students in how to efficiently use the feedback in order to improve their proficiency and ability as English writers [Williams, 2003]. In this line, Truscot [1996] also made an insensitive attack on error correction in writing classes; to the extent that error correction was thought to be harmful and therefore must be eliminated. Truscott asserted that the error correction research in L2 writing was certain in showing that correction was unproductive in assisting improvement in student writing, and at last he mentioned that although students clearly want correction, that doesn't mean that teachers should do what they want them to do. likewise, many years before the publication of Truscott's article, a research done by Kepner [1991, quoted in Ferris, 2004] demonstrated that learners who were given error feedback on their journal entries made considerably fewer errors than those who were only given "message related" comments. In another study, Lalande [1982] results showed that both treatment groups including those who received direct feedback and those who received indirect feedback improved in accuracy in time but that the achievements of the "indirect" group were better.

In the same way, there are many other researches that did not discover that error feedback by the teacher to be considerably more efficient for developing accuracy in L2 
student writing than content-related comments or no feedback. [Smeke, 1984; Kepner, 1991; Polio, et al. 1998]. Nevertheless, Smeke's discovery of impacts of error correction on accuracy and negative impacts on fluency may not have been due totally to the diverse treatment methods but also to the differences in the amount of writing practices. Anyway, recently, many studies have reported positive results for the existence of error correction, use, and usability [Lalande, 1982; Ferris, 1995; Ferris and Helt, 2000]. In fact, most learners look ahead to and value the feedback they receive in writing, and results extracted from a research has shown that it seems there is a relationship between active correction of errors and progress in writing skills. Ferris [1995] has put emphasis on the value that students give to writing accurately and their identified need to get corrections from the instructor. In addition, according to Lee [1997] there is research proof to show that L2 learners want error feedback and think that it is beneficial for them [Leki, 1998].

Nevertheless, a vital feature declared by Truscott [1996] who, actually, opposes grammar correction is the inevitability of not treating every linguistic group [lexicon, syntax, and morphology] as corresponding since these categories symbolize separate learning areas that are learnt during different stages and through different procedures. However, the majority researchers [Lalande, 1982; Smeke, 1984; Ferris and Roberts, 2001] have the same opinion about the fact that corrections are beneficial for the learners as long as they are reliable and organized. Anyway, it is apparent that marking can be a boring classroom task. Hyland [2003] argues that instructor's correction rarely brings development in next writing since teacher correction is repeatedly regarded by both teachers and students - as a stop sign to the writing procedure. By means of reducing the harmful outcomes of marking errors without reducing the advantages of the teacher's careful attempts, Hyland [2003] proposed 'minimal marking' and taped commentary to make feedback more fruitful and interactive. 'Minimal marking' can be done by correction codes. It can leave a room for active correction by the learner rather than reading the discouraging corrections of the instructor which are written in red. Via decoding the correction signs, students have the chance of identifying the errors and correct them for re-examination by the teacher later on. In his research regarding the impacts of graded versus upgraded compositions, Chastain [1990] found that even though there was no major distinction between the quantity and kinds of errors, "in some ways the expectation of a grade may influence student's writing in some positive ways. Students in this study wrote longer papers containing longer sentences and a higher number of complex sentences." (p. 14). Corrections put a weight on what is corrected; therefore exclusive surface-level error correction puts emphasis on form. It is probable that students are motivated and encouraged by the error -correction and that the effects will become apparent over time [Ferris, 2004].

According to the results of studies learners show development from first draft to last version of the same essay and little perfection between first drafts of first and last papers; so it is likely that feedback in this condition has not had a long-lasting impact on writing ability. However, students revealed an increased aptitude to effectively recognize errors. The most important activity in writing is for learners to learn to write. through writing, the students is engaged in a multifaceted procedure which requires the knowledge of content which is to be written about, the technical information that allows the management of content (e.g. knowledge of syntactic form) and the practical information that permits the production of a piece of writing of a specific type [Hillocks, 1998]

Comprehending the significance of supplying feedback does not essentially enable teachers to provide suitable feedback. Instructors should find the accurate way of giving feedback to learners. Johnson [1988] suggested two different conditions in which a learner may get things incorrectly.

Firstly, it is that the learner basically does not have the proper familiarity, and thus the knowledge or ability that the learner has is faulty or imperfect.

Secondly, it is the fact that a learner lacks processing capability. The problem here is not about whether the learner's information is imperfect or not; the problem is that the learner has obscurity performing the knowledge $\mathrm{s} /$ he has acquired in operating situations. Williams [2003] suggested that "many kinds of improvements that can be made for feedback on form can also be made for feedback on content" (p. 55). The collapse of written comments regarding content is due to a combination of using incoherent, indistinct comments together with not training learners in how to correctly use the feedback in order to have development in their writing ability. According to Williams, instructors should continuously use an average set of understandable and direct comments and questions to point out the place and type of content feedback. The comments of this kind and the questions should focus the learners' attention on the contents of their writing and the procedure they chased instead of simply showing the areas that the instructor thought to be appealing or the parts which were missing. As Leki [1990] has mentioned, these types of questions along with comments may be beneficial to construct a dialog between the learner and the instructor in order to provide both with a more apparent understanding of how the task was and should be considered and performed. Moreover, the instructors should familiarize their students with the kinds of comments, as well as grammar, that will be utilized and train students in how to use these comments. If the teachers do not train their students in how to utilize these comments in order to make their writing ability improve, students may probably neglect the comments, misunderstand them or not be able to use them correctly [Kroll, 2001]. According to Williams [2003], instructors should have a good idea about a useful method of feedback that deals with the limitations of common methods of feedback, the positive facets of them and the needs of learners. One of the most important aspects of any writing course is its goals which need to be taken into account when specifying how to provide learners with effective feedback. If the feedbacks which are provided with the teacher do not 
match the assignments or goals of the course, they may cause trouble for the students in knowing how to respond to them correctly. Among all these, there are concerns, of course and assignments objectives, the writing procedure and the type of the provided feedback.

Obviously, more investigation is required. Even though Hillocks [1998] in his comprehensive abstract of first language research found that generally, feedback has little impact, he motivates researchers to carry on looking at feedback because there are still a lot of variables which have not been investigated. Ferris's [2004] also believed that further research is needed in this field.

\section{Methodology}

The components of this research are as follows:

\subsection{Participants}

In order to perform this study, the researcher needed some participants to cooperate with him. The population of this research was composed of 2 Iranian Intermediate EFL classes with 20 students in each class at Iranmehr institute. The book being taught to these students was Top Notch. The participants included 26 female and 14 male students of around eighteen to thirty two years old.

\subsection{Instruments}

A pretest and post-test were utilized in order to quantify the progress among the students. This pretest and posttest were comprised of 20 grammar tests retrieved from IBT TOEFL tests in 2 groups of 1 identification of active and passive voices and 2) double choice items. The questionnaire is provided in Appendix 1.

\subsection{Procedure}

As mentioned earlier, the participants were divided into two groups, one group being exposed to teacher correction (Control group) and the other group to peer correction via CALL (experiment group). The members of control group were asked to write a text on the subject given by the instructor at the end of each session in which they were supposed to use as much passive voice as possible and next session, after they had submitted their written assignments to the instructor, it was instructor's turn to provide students with his comments on their performance. The CALL group members, on the other hand, were divided to ten groups of 2 and were asked to build a weblog for themselves and provide their team mates with the address of each other's weblogs. Each student was supposed to read his/her team mate's weblog every other day and put comments on his/her written assignment given by the instructor at the end of each session (just like the control group). The study was conducted within 2 weeks. As mentioned earlier, before starting the period, a pretest was given to both groups and after the two-week period, the same test was provided to them again as post-test to see which group (control or experiment) would perform better in post-test. For grading the tests, the number of correct items was counted and compared in pretest and posttest.

\section{Data Analysis}

In order to analyze the data gathered via pretest and post-test, the scores of students in both tests were extracted and the percentage, mean and standard deviation of total progress in each group was calculated. Then a T-test was devised in order to verify the difference between means of both groups since the two groups of candidates were independent from each other. The independent $t$ test compares the means between two unrelated groups on the same continuous, dependent variable. The SPSS ttest procedure allows the testing of equality of variances (Levene's test) and the tvalue for both equal- and unequal-variance. It also provides the relevant descriptive statistics. To implement independent $t$ test the study should meet the following set of assumptions:

1. Independent variable consists of two independent groups.

2. Dependent variable is either interval or ratio.

3. Dependent variable is approximately normally distributed

4. Similar variances between the two groups (homogeneity of variances)

In this study particularly the first two assumptions are met, since both independent and dependent variables are interval.

Statistics are provided in tables 4-1, 4-2, 4-3, and 4-4.

Table 1. Group Statistics for Pretest.

\begin{tabular}{lllll}
\hline & Groups & N & Mean & Std. Deviation \\
\hline \multirow{2}{*}{ pretest } & Control & 20 & 19.1020 & 5.82825 \\
& Experimental & 20 & 20.7381 & 4.53205 \\
\hline
\end{tabular}

Table 2. Independent Samples Test for Pretest.

\begin{tabular}{|c|c|c|c|c|c|c|c|c|c|c|}
\hline & & \multicolumn{2}{|c|}{$\begin{array}{l}\text { Levene's Test for } \\
\text { Equality of Variances }\end{array}$} & \multicolumn{7}{|c|}{ t-test for Equality of Means } \\
\hline & & \multirow[t]{2}{*}{$\mathbf{F}$} & \multirow[t]{2}{*}{ Sig. } & \multirow[t]{2}{*}{$\mathbf{t}$} & \multirow[t]{2}{*}{ df } & \multirow{2}{*}{$\begin{array}{l}\text { Sig. (2- } \\
\text { tailed) }\end{array}$} & \multirow{2}{*}{$\begin{array}{l}\text { Mean } \\
\text { Difference }\end{array}$} & \multirow{2}{*}{$\begin{array}{l}\text { Std. Error } \\
\text { Difference }\end{array}$} & \multicolumn{2}{|c|}{$\begin{array}{l}95 \% \text { Confidence Interval } \\
\text { of the Difference }\end{array}$} \\
\hline & & & & & & & & & Lower & Upper \\
\hline \multirow{2}{*}{ Pretest } & $\begin{array}{l}\text { Equal variances } \\
\text { assumed }\end{array}$ & 2.225 & .139 & -1.476 & 89 & .143 & -1.63605 & 1.10836 & -3.83834 & .56623 \\
\hline & $\begin{array}{l}\text { Equal variances } \\
\text { not assumed }\end{array}$ & & & -1.505 & 88.215 & .136 & -1.63605 & 1.08732 & -3.79681 & .52470 \\
\hline
\end{tabular}


Table 3. Group Statistics for the post-test.

\begin{tabular}{lllll}
\hline & Groups & N & Mean & Std. Deviation \\
\hline \multirow{2}{*}{ post-test } & Control & 20 & 19.2245 & 5.89585 \\
& Experimental & 20 & 18.1429 & 5.18239 \\
\hline
\end{tabular}

Table 4. Independent Samples Test for the post-test.

\begin{tabular}{|c|c|c|c|c|c|c|c|c|c|c|}
\hline & & \multicolumn{2}{|c|}{$\begin{array}{l}\text { Levene's Test for } \\
\text { Equality of Variances }\end{array}$} & \multicolumn{7}{|c|}{ t-test for Equality of Means } \\
\hline & & \multirow[t]{2}{*}{$\mathbf{F}$} & \multirow[t]{2}{*}{ Sig. } & \multirow[t]{2}{*}{$\mathbf{t}$} & \multirow[t]{2}{*}{ df } & \multirow{2}{*}{$\begin{array}{l}\text { Sig. (2- } \\
\text { tailed) }\end{array}$} & \multirow[t]{2}{*}{ Mean Difference } & \multirow{2}{*}{$\begin{array}{l}\text { Std. Error } \\
\text { Difference }\end{array}$} & \multicolumn{2}{|c|}{$\begin{array}{l}95 \% \text { Confidence Interval of the } \\
\text { Difference }\end{array}$} \\
\hline & & & & & & & & & Lower & Upper \\
\hline \multirow{2}{*}{ post-test } & $\begin{array}{l}\text { Equal variances } \\
\text { assumed }\end{array}$ & 1.131 & .290 & .922 & 89 & .359 & 1.08163 & 1.17305 & -1.24920 & 3.41246 \\
\hline & $\begin{array}{l}\text { Equal variances } \\
\text { not assumed }\end{array}$ & & & .931 & 88.936 & .354 & 1.08163 & 1.16141 & -1.22608 & 3.38935 \\
\hline
\end{tabular}

As it is shown in tables 4.3 and 4.4 , the analysis indicated that there was no significant difference between the two groups since the significant level was well above 0.05 . Since the findings indicated no impact from the part of the independent variable, or corrective recast, on the dependent variable, grammar acquisition, and the $t$ value obtained in post-test was somehow meaningless in terms of statistical significance, it was impossible conceive any kind of impact from the part of the treatment program.

This study found that corrective recast had statistically no clear impact on grammar acquisition of the Iranian EFL learners.

\section{Discussion}

As the results of this study showed, Corrective Recast had no impact on learner's grammar acquisition. Based on the outcomes of the post-test, integration of peer corrective recast in CALL does not have a significant impact on the Iranian EFL learners' grammar acquisition. This study concluded that students felt more convenient to accept a supervisor's comments on their essays about their grammatical errors than their peers' comments. This study showed that the participants of the control group who received the professor's comments were more active and motivated to write their essays every week on time than the participants of the experimental group who had to give and receive peer corrective recast on each other's essays in their weblogs. It seems that the students do not trust their peers' grammatical knowledge so that they could not accept their peers as a suitable judge about their grammatical errors or in general writing ability. According to the findings of this research it seems that the Iranian EFL learners seem to prefer to follow the conventional or traditional methods of learning than new methods which they are not used to.

Integration of peer corrective recast in CALL for teaching grammar will let the students get some corrective feedback to correct their grammatical errors in writing, which gives them little anxiety compared to the teacher's feedback, and they will be given a chance of unlimited editing. Although the results of this study indicated that peer corrective recast does not have a significant effect on the grammar knowledge progression of the students, but it still seems that using CALL programs in writing classes has its benefits like reducing the anxiety of the students, making them feel more comfortable so that they can concentrate even more on their achievement. This will also help students to promote the sense of independence in language learning and group work among their peers and overcome their fears in writing since they are not forced to do their assignments in the classroom in a conventional manner which would bring them some anxieties and inconvenience. Finally as the last implication, integration of technology in education requires significant investments in hardware, software, man power, support, training, etc. and all this demands huge budgets, hence recognizing the effect of this integration might even be of some help to justify these kinds of investments.

\section{Conclusion}

English foreign language student's performance was evaluated in 2 ways: one group by their peers through recast and the other group by the teacher, via traditional methods to see which method was more effective in teaching grammar, peer corrective recast or instructor's corrective hints. The text book used by the instructor during this experimental course was Top Notch. The number of errors could determine the results of pretest and posttest. Then frequency, mean and Standard Deviation were used for providing the results and statistics. Finally, a T-test was devised in order to verify the difference between means of both groups. This study found that corrective recast had statistically no clear impact on grammar acquisition of the Iranian EFL learners. Students felt more convenient to accept a supervisor's comments on their essays about their grammatical errors than their peers' comments. Participants of the control group who received the professor's comments were more active and motivated to write their essays every week on time than the participants of the experimental group who had to give and receive peer corrective recast on each other's essays in their weblogs. 


\section{Appendix}

\section{Questionnaire:}

Name: Age:

\section{Section 1: In Which Category Each of the Following Sentences Fall: Active or Passive?}

1. Your bicycle has been damaged.

Active

Passive

2. The dog bit the boy

Active

Passive

3. Rules are made to be broken

Active

Passive

4. Most of Class is reading the book

Active

Passive

5. Seeking to lay off workers without taking the blame, consultants were hired to break the bad news.

Active

Passive

6. The leaders are seeking a fair resolution to the crisis

Active

Passive

7. He tried to act cool when he slipped the puddle, but other students still laughed at him.

Active

Passive

8. To save time, Kristine wrote the paper on a computer

Active

Passive

9. Mistakes were made

Active

Passive

10. Research will be presented by Jack at the conference

Active

Passive

\section{Section 2: Select one of the Items Which Best Matches the Sentence}

11. Everybody By the terrible news yesterday.

A. Shocked

B. Was shocked

12. Mr Green At the university since 1989.

A. Has been teaching

B. has been taught

13. Not much........ about the accident since that time.

A. has said

B. has been said

14. A new book

A. will publish by that company next year.

B. will be published

15. He ...... the girl's name now.

A. remembers

B. is remembered

16. The secretary

A. introduced

B. was introduced 
17. Or plan by the members of the committee

A. is being considered

$\mathrm{B}$. is considered

18. $\mathrm{He}$ responsible for the accident.

A. was holding

B. was held

19. A prize to whoever solves this equation.

A. will be giving

B. will be given

20. When the manager arrived, the problem

A. had already been solved

B. had already solved

\section{References}

[1] Bartholomae, D. (1980). The Study of Error. College Composition and Communication, 31, 253-69.

[2] Chandler, J. (2003). The Efficacy of Various Kinds of Error Feedback for Improvement in the Accuracy and Fluency of L2 Student Writing. Journal of Second Language Writing, 12, 267-296.

[3] Chastain D. T. (1990). Developing Second Language. From Theory to Practice. IL, Chicago: Ran McNally.

[4] Ferris, D. R. (1995). Can Advanced ESL Students Be Taught to Correct Their Most Serious and Frequent Errors? CATESOL Journal, 8, 41-62.

[5] Ferris, D. R. (2002). Treatment of Error in Second Language Student Writing. MI: University of Michigan Press.

[6] Ferris, D. R. (2003). The "Grammar Correction" Debate In L2 Writing: Where Are We, and Where Do We Go from Here? (And What Do We Do in The Meantime). Journal of Second Language Writing, 13, 49-62.

[7] Ferris, D. R., \& Hedgcock, J. S. (1998). Teaching ESL Composition: Purpose, Process, and Practice. Mahwah, NJ: Lawrence Erlbaum Associates.

[8] Ferris, D. R., \& Roberts, B. (2001). Error Feedback in L2 Writing Classes: How Explicit Does It Need to Be? Journal of Second Language Writing, 10, 161-184.

[9] Ferris, D. R., Chaney, S. J., Komura, K., Roberts, B. J. \& McKee, S (2000). Perspectives, Problems, and Practices in Treating Written Error. Journal of Second Language Writing, 16, 38-60.

[10] Ferris, D. R., \& Helt, M. (2000). Was Truscott Right? New Evidence on the Effects of Error Correction in L2 Writing Classes. Paper Presented at Proceedings of the American Association of Applied Linguistics, San Diego, CA.

[11] Fox, J. (1984). Computer-Assisted Vocabulary Learning. ELT Journal, 38, 27-33.

[12] Frantzen, D. (1995). The Effects of Grammar Supplementation on Writing Accuracy in an Intermediate Spanish Content Course. Modern LanguageJournal, 79 (4), 329-344.

[13] Hardisty, D., \& Windeatt, S. (1989). The Internet (Resource Books for Teachers). USA: Oxford University Press.

[14] Hillocks, G., Jr. (1998). Teaching Writing as Reflective Practice. New York: Teachers College Press.

[15] Hyland, F. (2003). Focusing on Form: Student Engagement with Teacher Feedback. System, 31 (2), 217-230.

[16] Johnson, D. W., \& Johnson, R. T. (1998). Learning Together and Alone: Cooperative, Competetive, and ndividualistic Learning (5 ed.). Boston, MA: Allyn and Bacon.

[17] Johnson, M. K. (1988). Functional Forms of Human Memory. New York: Oxford University Press.

[18] Kepner, C. (1991). An Experiment in the Relationship of Types of Written Feedback to The Development of Second Language Writing Skills. TheModern Language Journal, 75 (3), 305-312.

[19] Kroll, B. (2001). What Does Time Buy?ESL Student Performance on Home versus Class Compositions. In: Kroll, $B$. (Ed.), Second Language Writing Research Insights for the Composition. UK: Cambridge University Press, pp. 140-154.

[20] Lalande, J. F. (1982). Reducing Composition Errors: An experiment. Modern Language Journal, 66, 140-149.

[21] Lee, I. (1997). ESL Learners' Performance in Error Correction in Writing: Some Implications for College-Level Teaching. System, 25, 465-477.

[22] Leki, I. (1990). Twenty Five Years of Contrastive Rhetoric: Text Analysis and Writing Pedagogies. TESOL Quarterly, 25 (2), 123-143.

[23] Leki, I. (1998). Coping Strategies of ESL Students in Writing Tasks across the Curriculum. TESOL Quarterly, 2 (2), 235260.

[24] Li, x., \& Cao, R. (2006). Integrating Computer-Mediated Communication into an EAP Course. Research Article (4), 589-600.

[25] Lightbown, P. \&Spada, N. (1999). How Languages Are Learned. UK: Oxford University Press.

[26] Murphy, T., \& Jacobs, G. M. (2000). Encouraging Critical Collaborative Autonomy. JALT, 22, 228-244.

[27] Polio, C., Fleck, N., \&Leder, N. (1998). "If Only I Had More Time": ESL Learners' Changes in Linguistic Accuracy on Essay Revisions. Journal of Second Language Writing, 7, 4368.

[28] Powell, B. (1998). The Use of Computer Assisted Language Learning. Forum for Modem Language Studies, 2, 184-194. 
[29] Richards, J. (1985). The Context of Language Teaching. London: Cambridge University Press.

[30] Richards, J. C., \& Schmidt, R. (2002). Longman Dictionary of Language Teaching and Applied Linguistics (3 ed.). London: Pearson Education.

[31] Robb, T., Ross, S., \&Shortreed, I. (1986). Salience of Feedback on Error and Its Effect on EFL Writing Quality. TESOL Quarterly, 20, 83-93.

[32] Rollinson, P. (2005). Using Peer Feedback in the ESL Writing Class. ELT Journal, 59, 23-30.
[33] Smeke, H. (1984). The Effects of the Red Pen. Foreign Language Annals, 17 (2) 195- 202.

[34] Truscott, J. (1999). The Case for "The Case Against Grammar Correction in L2 Writing Classes": A Response to Ferris. Journal of Second Language Writing, 8 (2), 111-122.

[35] Williams, J. C. (2003). Providing Feedback on ESL Students Written Assignments. TESL Journal, 3, 111-123.

[36] Zhang, S. (1995). Reexamining the Affective Advantage of Peer Feedback in the ESL Writing Class. Journal of Second Language Writing, 4, 209-22. 